\title{
Conducting Interviews for News Stories ${ }^{1}$
}

\author{
Ricky Telg and Lisa Lundy²
}

This publication on interviews for news stories is the fifth of a five-part series on news media writing. This series also covers an introduction to news media writing, news writing for print, grammar and punctuation, and news writing for television and radio.

\section{Introduction}

In order to write a good news story for print, television, or radio, you have to conduct interviews with the people who have the information you need. An interview is the process of asking good questions so you can get good answers for your news story. If you have never conducted an interview, the idea of doing one may seem a little scary. If you imagine that the interview is just a conversation with the other person, doing the interview will be much less frightening. This publication provides some tips to follow as you conduct a news story interview.

\section{Before the Interview}

- Set aside time to conduct the interview. Unless the person being interviewed is on an extremely tight schedule so that the interview can only take a few minutes, try to schedule a little extra time so that you and the person being interviewed do not feel constrained for time. Be sure you plan for plenty of time to get to the interview.

- Dress appropriately. Impressions make an impact on the person being interviewed. Dress up a little or wear your organization's official attire. A nametag is helpful so the interviewee can easily remember your name during the conversation. Avoid jeans or shorts.
- Prepare at least 10 questions in advance. These questions should pertain directly to the topic you need information about. Think about what your audience needs to know as you prepare the questions. What does your audience want to know?

- Understand the subject matter (at least a little bit). The person being interviewed is the expert on the topic. Otherwise, you would not have called on the person for an interview. However, it is good practice to do at least a little research on the topic beforehand so that you can ask good questions. If the interviewee has participated in other interviews, it can be helpful to read, watch, or listen to those.

- Be on time for the interview. Being prompt makes a good impression on the person being interviewed.

\section{During the Interview}

- If you plan to use an audio recorder during the interview, first obtain the interviewee's permission to do so. If you are doing a television interview, before you arrive let the person being interviewed know that you will have a video camera. Be clear with them when you start and stop recording.

- Take good notes. Do not rely on an audio recorder. Batteries do die. You may also notice nonverbal cues that aren't picked up by a recorder. For example, you may want to note if the interviewee smiles or looks confused by a question.

1. This document is AEC532, one of a series of the Department of Agricultural Education and Communication, UF/IFAS Extension. Original publication date January 2015. Revised June 2021. Visit the EDIS website at https://edis.ifas.ufl.edu for the currently supported version of this publication.

2. Ricky Telg, professor, and Lisa Lundy, professor, Department of Agricultural Education and Communication, UF/IFAS Extension, Gainesville, FL 32611.

The Institute of Food and Agricultural Sciences (IFAS) is an Equal Opportunity Institution authorized to provide research, educational information and other services

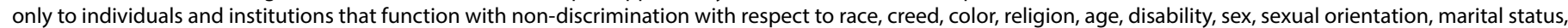

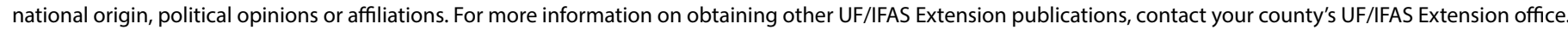
U.S. Department of Agriculture, UF/IFAS Extension Service, University of Florida, IFAS, Florida A \& M University Cooperative Extension Program, and Boards of County Commissioners Cooperating. Nick T. Place, dean for UF/IFAS Extension. 
- State the interview's purpose. What do you want to cover in the interview?

- Break the ice with light conversation. Make the person being interviewed feel at ease.

- Let your subject do the talking. Do not break in or interrupt while someone is answering a question. Wait until the person has completed answering a question.

- Get at least three good, insightful direct quotes. This should be your goal in an interview.

- Get correct information. Ask persons you interview to provide the correct spelling of their names and their job titles. Do not assume you know what they are. One way of getting their correct information is to ask for their business card.

- Collect more information than you think you will need.

- Do not be bashful about asking the person to repeat something important or provide further explanation/ clarification. It is better to have something repeated and get the information correct than to get it wrong.

- Be aware of your surroundings. A few notes about the room and other surroundings may be useful in a feature story to help set the mood of your story.

\section{Asking Questions}

Listen carefully to the answers and take good notes. As the person talks, ask yourself, "What is my lead going to be? Do I understand enough to state a theme clearly and support it with quotes?" In addition:

- Never plunge in with the tough questions. Break the ice by explaining who you are and what you are doing.

- Be pleasant but purposeful. You are there to get information, so do not be timid about asking questions.

- Use the list of questions you prepared. Start with the easier questions, and then move to more in-depth questions or ask one that comes to mind.

- Do not be afraid to deviate from your set of questions. If a prepared question is no longer suitable, move to the next question. Some answers prompt additional questions. Ask them as they arise. Listen to what the person is saying. One question should logically follow another.

- Be objective. Do not offer your opinions on the subject. You are there to report, not to editorialize.

- Stay on track. If the interviewee strays too far from the subject, ask a specific question to redirect the conversation.
- Avoid yes/no questions. These only provide yes/no answers.

- Start with questions focusing on the five Ws and H: who, what, when, where, why, and how.

- Get in the habit of asking more probing questions, such as, "What do you mean?" or "Why is that?" or "Can you tell me more about that?"

\section{At the End of the Interview}

- As the interview comes to a close, take a few minutes to skim your notes. If time allows, ask the interviewee to clarify anything that you did not understand.

- Ask for permission to call back or e-mail later for more information, if necessary.

- Smile, thank the interviewee, and leave.

- Fill in the blanks immediately.As soon as the interview is over, while it is fresh in your mind, go back to your notes and fill in any blanks that you were not able to write down during the interview.

\section{Types of Interview Questions}

Following are some of the questions that you might want to ask:

- Close-ended questions provide short answers. The answer to the example close-ended question below would provide just a list of the positive courses.

- Closed-ended question: "In which college courses have you had the most positive experiences?"

- Open-ended questions provide longer answers. The answer to the example open-ended question below would provide a much longer response.

- Open-ended question: "What's your opinion of Ms. Hightower's class?"

- Probe questions follow up on something the interviewee has said.

- Close-ended question: "In which college course have you had the most positive experiences?"

- Answer: "Ms. Hightower’s class."

- Probe question: "What positive experiences have you had in this class?"

- A mirror question repeats part of the person's answer, prompting the person to explain an answer further. A mirror question is often paired with a probe question. 
- Probe question: "Why do you think people are saying positive things about Ms. Hightower's class?"

- Answer: "Because she's fair, has knowledge about the subject, and seems to really care about students."

- Mirror question: "You say she's fair. Why is being fair important to students?"

- The yes/no question is the most close-ended of close-ended questions. The answer can only be one of two options: yes or no. On their own, yes/no questions provide little information for most news and feature writers. Use yes/ no questions to set the stage for other questions that would provide more in-depth information.

- Yes/no question: "Do you think Mr. Smith is a good teacher?" (Answer would be "yes" or "no." Then use a probe question to expand on the interviewee's answer.)

- Leading questions are considered unethical by many news writers. A leading question strongly suggests the "right" answer to an interviewee. The question below would make the interviewee feel that the "correct" response was that Mr. Smith was a great teacher, even if the interviewee did not feel that way.

- Leading question: "Everyone I've interviewed says Mr. Smith is an outstanding teacher. What's your opinion?"

\section{Additional Information}

The Associated Press. (2022). The Associated Press stylebook and briefing on media law (55th ed.). New York: The Associated Press.

Burnett, C., \& Tucker, T. (2001). Writing for agriculture: A new approach using tested ideas (2nd ed.). Dubuque, IA.: Kendall/Hunt.

Oliu, W. E., Brusaw, C. T., \& Alred, G. J. (2007). Writing that works: Communicating effectively on the job (9th ed.). Boston: Bedford/St. Martin's.

Telg, R. \& Irani, T.A. (2012). Agricultural communications in action: A hands-on approach. Clifton Park, NY: Delmar. 